\title{
Conservation's Roots: Managing for Sustainability in Preindustrial Europe, 1100-1800. Edited by Abigail P. Dowling and Richard Keyser.
}

\author{
Environment in History: International Perspectives 19. New York: Berghahn
}

Books, 2020. 364 pp.

\section{András Vadas}

Institute of Historical Studies, Department of Medieval History, Eötvös Loránd University, H-1088

Budapest, Múzeum körút 6-8; vadas.andras@btk.elte.hu

Words such as sustainability, conservation, nature protection, and environmental footprint have become so fashionable that as it often happens in such cases, they have completely lost their meaning. These notions appear in everyday speech, in the media, as well as in the scholarly literature, in many cases with considerably different agendas in different contexts. As the importance of the present environmental crisis has entered the discourse in social sciences and humanities, increasing attention has been paid to its historical aspects. Scholars have discovered-or invented rather-the roots of modern environmentalism and conservation in pre-modern times, trying to apply modern concepts for past land-use practices. Doing away with this rather damaging approach is the main background to the book presented here. To use its editors' words, the volume is a product of "the frustration that we, the editors, shared concerning the unawareness and simplistic narratives about preindustrial environmental history." In this case, the frustration found fertile ground, as the volume is an exceptionally well-thought-out contribution to the idea of conservation and sustainable management in pre-modern Europe.

When dealing with pre-modern conservationism and sustainable management, research mostly draws on the formation of state forestry in early modern times. In many cases, from the fifteenth or rather the sixteenth century onwards, scholars interpreted efforts of different state offices (chambers) to conserve forests held by monarchs as new developments. However, these efforts were not new, but mostly extended formerly existing practices. The individual studies in this book address these practices in the medieval and early modern period, mostly focusing on two resources, i.e., forests and water. 
Neither the introduction by the editors, nor the afterword are mere summaries of the articles in the volume. While the introduction carefully sets the scene, pointing to shortcomings of previous studies in historical sustainability, in the afterword Paul Warde lays out the tasks for future research. Apart from these, the volume includes twelve chapters divided into three parts: the first addresses multiple-use resources, the second focuses on sustainability in water resource-use, while the third is dedicated to forests.

The first third of the volume focuses on the problem of conservation and sustainable multiple-use resource management in parklands, hunting parks, and heathlands. The latter, probably lesser known to those who focus their research on Central Europe, is a shrubland vegetation that used to be widespread in northwest Europe but has heavily decreased over the past centuries. Apart from analyzing landscapes of different uses, Dolly Jørgensen's study discusses how to control pigs, these important inhabitants of the medieval countryside and city. The studies in this part of the book are somewhat less coherent as they address diverse problems, which does not mean that they lose the focus of the volume. Each study offers a clear idea of clearly how practices that were meant to regulate resource-use took form and became dominant.

Let me point to two issues in the first set of papers that make them valuable not only in the study of sustainability, but also in social, economic, and legal history. The first is that in these areas and landscapes the authors identify a clear tendency for people to take control over every single resource. In the northern part of Italy, as demonstrated by Cristina Arrigoni Martelli, urban authorities' increasing control over hunting is seen in the late medieval period. While the inhabitants of the contado practiced hunting for smaller game with only a few restrictions-that were meant to ensure the lasting availability of these animals-in legislative sources, increasing control by expanding towns is well expressed. They first marked out certain spaces where no hunting was allowed, then gradually extended these restrictions to larger areas, and finally went as far as to prohibit catching birds by mills and their dams. The control is expressed in entirely different ways in legislations regulating the common heathland-use in the Campine region in the Low Countries studied by Maika De Keyzer. The exploitation of these common pastures was not solely based on customs but was controlled by very detailed sets of local laws, many of which had been extant from early modern times. These bottom-up regulations were no less detailed than those legislated by podestàs in Italian towns. Just to mention but one example the author provides: people had the right to mine peat in the common heathlands, a fuel of increasing importance in late medieval and early modern times. However, it was forbidden to simply abandon the pits after mining, as leaving thin layers of soil open would have been a danger to effective herding. Accordingly, minders had to re-bury the pits in order to prevent sand movement. 
Partly connected to this, a second common element of the first studies is the emphasis on secondary and tertiary uses of landscapes. This is emphasized by Jørgensen, who points to the fact that pigs were driven not only to parklands to eat acorn, but also to ploughlands to eat up what was left there after the harvest. Similarly, Abigail P. Dowling's contribution addresses how an elite park, the primary goal of which was to serve as a hunting ground, made a significant income, amongst other things, from selling firewood and timber harvesting.

Three studies in the volume are dedicated to issues of water conservancy in premodern times. The scope of these studies is wide. While Michael Zeheter chose to discuss the fishing regulations at Lake Constance, Richard Hoffmann's paper gives a comparative study of European fishing regulations in the late medieval period. Both studies have their merits, as in many ways Hoffmann shows how the very detailed sets of regulations that Zeheter points to in a local context re-appear in regulations of distant areas of Europe. Both authors emphasize the two most important aspects of regulations: first, to supply fish for the communities, and second, to secure the lasting presence of fish in rivers and lakes, or by seashores. The last paper in this part by Eva Jakobsson introduces the readers to a peculiar Swedish "institution" called the King Vein (Kungsådra). As she argues, it was a form of royal control over the waterways of Sweden, meaning a share of the water flow that none of the actors had the right to back up.

The most important merits of the studies in the third part of the book dedicated to woodlands are, firstly, that they demonstrate that conservation practices expressed in early modern legislations are rooted in the Middle Ages (see especially Richard Keyser on France) and, secondly, that in addition to state administrations, local administrations were also keen on governing forest resources. The latter is demonstrated by Sara Morrison in the case of Sherwood Forest in England, and by Sébastien Poublanc on the example of forests in southern France. Both authors show that in early modern times local customs were very much respected in organizing local forestry, despite existing state forest regulations. The other important point that both authors make is that local regulations were indeed focused on serving local interests rather than supplying state needs (which would have been timber for ship building).

The last two chapters in this part of the book move away from Western Europe and discuss forest conservation practices in Prussia and East Central Europe (Czech lands and, to some extent, Hungary). Oliver Augé discusses Prussian forest management before the publication of Sylvicultura oeconomica by Hans Carl von Carlowitz in 1713. His paper shows that the forms of forest conservation Carlowitz proposed did not come ex nihilo but were indeed rooted in pre-modern practices widely applied in Prussia well before the early eighteenth century. The last paper, written 
by Péter Szabó, to some extent goes beyond many of the studies: because in addition to discussing forms of pre-modern forestry in East Central Europe, it problematizes how these practices were denied by modern state forestry, and then gradually re-discovered and re-applied in recent decades. His paper points to a practice whose sources are scarce, and which probably would deserve further study, namely litter raking. He demonstrates that while coppicing and herding in wood-pastures, increasingly re-introduced in past decades, are shown to have been sustainable ways to exploit woodlands and have proved to be important for biodiversity and historical landscape preservation, litter raking seems to have removed major amounts of minerals from the forests, harming their ecosystem-balance. The latter discovery also points to a significant perspective, namely the need for a non-romanticizing view of pre-modern practices, which in recent years has been increasingly characteristic of both scholarly works and communications to wider publics.

The volume reflects great editorial care. Almost every study supports the main thesis of the collection, which is that while there was a clear tendency for sustainable forest (land) and water resource management in pre-modern times, this motivation was social and economic, rather than ecological. Not only do the papers implicitly communicate with each other, but they also refer to each other, pointing to the commonalities or differences in practices in the areas studied. With very few exceptions, the papers draw on archival material that in many cases had seldom been studied previously, and even those that build on printed sources raise new perspectives and pose different questions than previous authors. Accordingly, the volume will undoubtedly become one of the key references in pre-modern sustainability studies. 